\title{
RETHINKING THE POLITICAL SYSTEM OF THE JÖCHID*
}

\author{
TAKUSHI KAWAGUCHI ${ }^{1}-$ HIROYUKI NAGAMINE $^{2}$ \\ ${ }^{1}$ Faculty of Letters, Fuji Women's University, Kita 16-jo, Nishi 2-chome, Kita-ku, \\ Sapporo, Hokkaido, 0010016, Japan \\ e-mail: kawa_taku34@jcom.home.ne.jp \\ ${ }^{2}$ Hokurei Junior-Senior High School, Shin'ei 448-1, Kiyota-ku, Sapporo, Hokkaido, Japan \\ e-mail: gamaja.yokaton.13@gmail.com
}

The aim of this paper is to reconstruct the history of the Jöchid, placing emphasis on the "inner sources of the Jöchid", especially on the Chingizz-näma. First, we re-examine the essence of the term "Golden Horde", and make an attempt to point out that the appellation "Golden Horde" used for the Jöchid may go back to earlier times than the late 16th century. Secondly, it is demonstrated that the Jöchid had been divided into Right and Left Wings after the reign of Toqtagha at the latest and this structure continued even after the unification of both wings by Toqtamïsh, a fact that historians in the Timurid Empire were also well aware of. Thirdly, the study shows that, at least by the late 14th century, it was recognised that the "White Horde" referred to the Right Wing or the entire Jöchid, while the "Blue Horde" to the Left Wing.

Key words: Jöchid, Čingīz-nāma, Golden Horde, Right and Left Wings system, White Horde, Blue Horde.

\section{Introduction}

Recent studies on the Jöchid (Jöchi Ulus, Golden Horde) are problematic in terms of both the research techniques employed and the historical sources. Historical research on the Jöchid started with Joseph Hammer-Purgstall in the 19th century, and since then the entire history of the Jöchid has been examined. However, although much recent research on the Jöchid states has produced interesting results, less attention has been payed to the global image of the Jöchid.

The most important historical sources for studying Jöchid history are the numerous coins and contemporary historical records such as documents and verse literature written inside the Jöchid state and the contemporary historical records written

\footnotetext{
${ }^{*}$ This paper is an enlarged and revised version of Kawaguchi-Nagamine (2013).
} 
outside the Jöchid domain including Persian historical ones written in the Ilkhanate and the Timurid Empires, Arabic historical records written in the Mamluk State and Russian historical records written in the Rus' principalities. However, there are limitations to using some of these historical records written outside the Jöchid domain because they lack reliable descriptions and give rise to conflicting interpretations.

The Chaghatay historical work Chingīz-nāma (hereinafter: $C h N$ ) edited by the historian Ötämish Hājī who served the Khiva Khanate, one of the Later Jöchid states, in the middle of the 16th century, has attracted the attention of researchers in recent years ${ }^{1}$. V. P. Iudin highly evaluates the historical records written inside the Later Jöchid states including $C h N$ ("inner sources of the Jöchid") ${ }^{2}$ as "the oral historiography of the Steppe" (Iudin 1992a, pp. 25-26; 1992b, p. 57). Concurring with Iudin's opinion, we have shown that these sources have the character of descriptive historical records (ChN, pp. xiii-xxv; Kawaguchi-Nagamine 2010). Other recent research on $C h N$ tends to affirm the character of the historical records in $C h N$ and utilise them for research on Jöchid history ${ }^{3}$.

Aside from the Tashkent manuscript, a manuscript owned by Rïzaeddin (18581936, also called Fakhreddin), a prominent " "ulamā" " of the Volga-Ural region was discovered in recent years (Mirgaleev 2011, pp. 14-19), thus the research environment of $C h N$ continues to evolve. A precise examination of the Rïzaeddin manuscript is expected to reveal new knowledge on Jöchid history in the 15 th century and open new avenues of enquiry.

In this paper, some mutually related problems of the political system of the Jöchid are analysed to attempt a reconstruction of Jöchid history. Namely, they are the appellations of this state, the Right and Left Wings system, and the problem involving the White Horde and the Blue Horde. Thus, the inner sources of the Jöchid including $C h N$ are positively utilised.

${ }^{1}$ First, V. P. Iudin published the Cyrillic transcription, the Russian translation, and the facsimile of the Tashkent manuscript of $C h N$ (ChN/Iudin). Subsequently, we have published the bibliographical notes, the annotated Japanese translation, the Roman transcription, and the Arabic critical text of the same manuscript $(C h N)$ (Kawaguchi-Nagamine 2010 revises the bibliographical notes of this edition partially).

${ }^{2}$ As "His Highness Dūst Sultān's historical work", which is presumed to have been handed down to the central figures of the Jöchid family, became the source of information of $C h N$ (ChN, pp. xxi, 20, 44; Kawaguchi-Nagamine 2010, p. 48), the records or recollections of the Jöchid at a certain time were likely inherited by the Jöchid states in a certain form. Based on these points, the historical records written in the Jöchid are called the "inner sources of the Jöchid" in this paper.

${ }^{3} \mathrm{~V}$. V. Trepavlov found a point of agreement between the description of the Muscovite Glinskii family's genealogy book and the description of $C h N$ (Trepavlov 2007a, pp. 328-342). This suggests the existence of the sharing of the historical facts and "the system of the historiography in the Qïpchaq Steppe based on original sources of information" presented by us ( $C h N$, pp. xxiii-xxv; Kawaguchi-Nagamine 2010, pp. 49-50). A. G. Gaev (2002, pp. 10-15) and I. Vásáry (2009b, pp. 371-385) identify Noqay's son Sasï Buqa in Muntakhab al-Tawārīkh-i Mu'īn̄̄ as Qara Noghay from the Toqa-Temürid in $C h N$, and also Mubārak Khwāja, the only Left Wing Ulus' ruler whose coins can be found, as a person of the Toqa-Temürid. Research that identifies the Toqa-Temürid persons in $C h N$ in genealogical sources, such as $M u$ ' $i z z$ al-Ansāb, has been conducted by Iudin and us (Iudin 1992b, pp. 72-74; ChN, p. 37, note 87). 


\section{On the Appellations of the State}

In this section, first the appellations of this state are re-examined because there are three main appellations - "Jöchi Ulus (ulīs-i jūchī/jöchi)", "Qïpchaq Khanate" and "Golden Horde (Zolotaia Orda)" - being used for this state. The way they are used differs by researcher and country. The "Qïpchaq Khanate"4 is said to be an appellation derived from the "Qïpchaq Steppe (dasht-i qipchāq)" where Jöchid was founded or from the "Qïpchaq tribe" who lived there, based on Arabic, Persian etc. sources. ${ }^{5}$ However, as these sources are outer sources of the Jöchid, the appellation "Qïpchaq Khanate" is considered to be a research appellation based on outer sources.

\subsection{The Notion of "Jöchid"}

Whether there can be regarded an official appellation of this state is a difficult question, but "Great Ulus (ulugh ulus)" and "Great Orda (ulugh ordu/orda)", which appeared in document sources such as the yarlïghs granted by Jöchid rulers (for example, the yarligh of Toqtamïsh in 1393 discussed in Section 3), are regarded by some as the official appellation (Izmailov 2009, p. 16; Mustakimov 2012, pp. 19-20) . $^{6}$

In contrast, the term ' $u l \bar{u} s-i j \bar{u} c h \vec{\imath}$ ' is often used for this state in the sources of the Mongol Empire or the Ilkhanate, including the Jāmi ' al-Tawārīkh of Rashīd alDīn, and many researchers have accepted it as the appellation of this state. However, as I. A. Mustakimov pointed out recently (Mustakimov 2012, pp. 13, 19), this term is not found in the document sources of the Jöchid and is hardly used in the sources written in the Later Jöchid states, for example, it is not found in ChN. Looking at the inner sources of this state, it is recognised as belonging to the Jöchid family. With these reservations in mind, in this paper we call this state the "Jöchid" and the period of the Jöchid states after the 15th century the "Later Jöchid"?

${ }^{4}$ To the best of our knowledge, the first scholar who connected the Jöchid with the "Qïpchaq" was Pétis de la Croix; he called Özbeg Khan the "King of Qïpchaq (Roy de Capfchac)" (Pétis de la Croix 1710, p. 506).

5 The "Qipchaq", the "Qïpchaq Steppe" and merely the "Steppe" found in these sources are, undoubtedly, the names of the ethnic group and geography that have a strong connection with the Jöchid, and, as stated by I. A. Mustakimov, we can regard these as being used as the ethnic and geographic appellations of the Jöchid in the 13th-14th centuries (Mustakimov 2012, pp. 12, 20). However, the rulers of the Jöchid were not called "Qïpchaq Khan" in the descriptions of the sources.

${ }^{6}$ The terms "ulugh ulus", "ulugh ordu/orda" are found in the documentary source material of the Crimean Khanate, and that is one of the reasons for the view that the Crimean Khanate intended to succeed the authority of the Great Horde (Collins 1991, pp. 370-371; Trepavlov 2010, pp. 98-100; Vásáry 2012, pp. 22-23).

${ }^{7}$ Although the common opinion viewing the collapse of the Great Horde in 1502 as the end of the Jöchid has been accepted, this issue is being re-examined (Collins 1991; Kawaguchi 1997, p. 278; Vásáry 2012). And the theory that defines the period of the Jöchid states after the 15 th century as "the Later Golden Horde" can also be found (Schamiloglu 1984, p. 283; 1986, p. 1). 


\subsection{What Is the "Golden Horde (Zolotaia Orda)"?}

The "Golden Horde (Zolotaia Orda)" is an appellation from The Russian Chronicles, and it first appears in Istoriia o Kazanskom tsarstve (hereinafter: IKTs), assumed to be written in the late 16th century (Vernadsky 1953, p. 140). The term "ordu/orda" means "residence of a nomadic state's ruler", that is to say, "royal pavilion (headquarters)", "royal court", "palace", and implicates a variety of groups and organisations such as empresses, servants, guardsmen, merchants and so forth, moreover, it frequently symbolises the nomadic state itself in the pre-modern era (Iudin 1992a, pp. 22-24; Mustakimov 2012, pp. 17-18). Next, "gold" is often connected with the rulers of nomadic states, including the Mongol Empire (cf. Vásáry 2009a, p. 68, note 8; JT, p. 287b). As for the pavilions of Jöchid rulers, some records state that the throne of Batu (r. ?-1256) inside the pavilion was "completely overlaid with gold" (Sinica, p. 214; Rubruck 1990, p. 132), and Özbeg (r. 1313-1341) was sitting in "the gold pavilion (qubba al-dhahab)" (Ibn Batțūtạ/DS, p. 383; Ibn Batțūtạ/G, p. 483). It is the appearance of "the gold pavilion" here that researchers have often regarded as the origin of the "Golden Horde" (Mitroshkina 1969; Bogatova 1970).

In contrast, after G. Vernadsky, researchers questioned the posterity of the appellation "Golden Horde" (Vernadsky 1953, pp. 138-140; Ostrowski 1998, p. xiii). These researchers indicate that this appellation appeared in IKTS of the late 16th century for the first time; that is to say, there is no earlier record of it, and the "Golden Horde" is not the appellation of the Jöchid, but merely an explanation about the colours of the pavilions. However, can we really conclude that the appellation "Golden Horde" goes back no further than the late 16th century?

The royal pavilion, the headquarters of the nomadic state's ruler, frequently symbolises the nomadic state itself. Here we introduce a very interesting description of Hei-da shi-lüe (黑鞋事略) (completed in 1237) written by Peng Da-ya (彭大雅) and Xu Ting (徐霆) of Nan-Sung (南宋), who visited the palace of Ögödei (r. 12291241), the ruler of the Mongol Empire, and consider what constitutes the essence of the "Golden Horde". The report of Peng Da-ya's visit in 1232-1233 runs as follows":

They call the place in which the pavilion of the Mongol ruler (韃主) is built a Horde (窩裏陀). It is the Golden Horde (金帳) (because it is supported by golden pillars). The place in which [pavilions of] empresses and subjects are built together is just called the Great Horde (大窩裏陀) (Hei-da shi-lïe, p. 58).

And the report of Xu Ting whose visit was in 1236 reads as follows:

When I, Xu Ting visited the steppe, [Mongol] built the Golden Horde. [omit] Its structure is as follows: it is a great felt pavilion on the steppe,

${ }^{8}$ According to N. Shiraishi, the palace of Ögödei which Peng Da-ya visited was the palace inherited from his father Chinggis in the Kherlen River basin, and is located in the present Avraga site (Shiraishi 2006, pp. 85-87). However, Ögödei transferred to Qaraqorum built as the capital in 1235, therefore, it seems that Xu Ting visited Qaraqorum. 
covered with felt above and below and fixed by no less than one thousand ropes. A willow-woven window is made in the centre for light. All of the threshold and pillars are covered with gold. That is the reason why it is called the Golden Horde (Hei-da shi-lüe, pp. 58-59).

It mentions here that it is called the "Golden Horde" because the threshold and the pillars are covered with gold. Ibn Batțūta described that "It [= the gold pavilion of Özbeg] is constructed of wooden rods covered with plaques of gold, and in the centre of it is a wooden couch covered with plaques of silver gilt" (Ibn Battūta/DS, p. 383; Ibn Bațtutạ/G, p. 483); Carpini described that "This pavilion [= the Golden Orda] was supported by columns covered with gold plates and fastened to other wooden beams with nails of gold" (Sinica, pp. 118-119; Carpini/M, pp. IX, 32; Carpini/D, p. 63). Furthermore, "the white pavilion with a gold threshold" appeared in $C h N$ as mentioned below, and the throne was "completely overlaid with gold" in Rubruck's description as mentioned above. That is to say, it was the "Golden Horde" because its threshold, pillars, throne and so forth were covered with gold. These important parts of the pavilions were covered with gold to embody the power and authority of its master, the ruler. It thus seems that the "Golden Horde" and the place where it was built came to symbolise the power and authority, and finally, the nomadic state itself.

As the term "Orda" was used commonly for Jöchid in The Russian Chronicles after the end of the 13th century, considering the very close intercommunion between Rus' society and the Jöchid, this term has very significant implications. This "Orda" can be interpreted as meaning the pavilion, the Jöchid ruler's headquarters, and at the same time, the Jöchid itself. Moreover, it provides the evidence that actually the Jöchid state was called "Orda" in Rus' society at that time. For that reason, "Zolotaia Orda" was recognised by the people at that time as not only the ruler's gold pavilion, but also the object symbolising the Jöchid itself.

This idea was preserved even in the Later Jöchid period whereby the Jöchid ruler's pavilion, that is to say, the Jöchid, was connected with gold. For example, the pavilion of the Batuid, the suzerain of the Jöchid, was connected with gold in the description of $C h N$ written in the Khiva Khanate?

The Khan [= Chinggis Khan] built three pavilions for those who visited the Khan. He built a white pavilion with a gold threshold (altun busaghalï aq örgä) for Sayïn Khan [= Batu], a blue pavilion with a silver threshold (kümüsh busaghalï kök orda) for Ejän [= Orda], and a grey pavilion with an iron threshold (bolat busaghali boz orda) ${ }^{10}$ for Shiban (ChN, pp. 8-9, 38a-38b).

When Tay Tughlï Begim called Khïḍr Khan and made [Khïḍr Khan] khan on the throne of Saray, she built the gold pavilion (altun termä)

${ }^{9}$ There is a view that "Zolotaia Orda" means only Batu's Ulus, not the entire Jöchid. But it seems that, as the Batuid were the suzerains of the Jöchid, "Zolotaia Orda" sometimes meant the entire Jöchid realm, sometimes only Batu's Ulus.

${ }^{10}$ As for the "grey pavilion/Grey Horde (boz orda)", see note 16, below. 
inherited from Öz Beg Khan and Jān Beg Khan [= Jānībeg] (ChN, pp. $41,53 a)$

Although it contains some legendary elements, "gold" was connected with Batu, Özbeg and Jānībeg (r. 1342/43-1357) in these descriptions; in addition, it is historically recognised that the gold pavilion was inherited by Jöchid rulers for generations. In this connection, we return again to the description of $I K T s$, "from the period of Batu, until the reign of just the Golden Horde (Zlatyia Ordy) of Tsar' Akhmat, son of Zelet-saltan ${ }^{11}$ " (PSRL/XIX, pp. 5, 195-196), which is said to be the first appearance of "Zolotaia Orda". From this description the author recognised the "Golden Horde" connected with "Tsar' Akhmat"; Ahmad, the ruler of the Great Horde (r. 1465?1481) goes back to the period of Batu ${ }^{12}$. There are several views about the author of $I K T s$, but the author was presumably a person who was well acquainted with the inside relations of the Kazan Khanate, one of the Later Jöchid states (Hamamoto 2011, pp. 29-45), and thus, its historical recognition is worthy of attention.

The expression "Golden Great Horde (Velikuiu Ordu Zlatuiu)" also appears in IKTs (PSRL/XIX, pp. 5, 195-196). Intriguingly, "gold" and "great" were sometimes used as synonyms in Turco-Mongol (Mustakimov 2012, p. 17), and the expression "Golden Great Horde" is one such example. Therefore, as Mustakimov also indicates (Mustakimov 2012, p. 20), the appellation "Golden Horde" may have been used as a synonym for the "Great Ulus/Horde (ulugh ulus/orda)" that appeared in the document sources.

Some researchers, furthermore, saw the possibility that people dared not use the appellation "Golden Horde", in order to avoid using the word "gold" to glorify the Jöchid, in spite of this appellation already being known in Rus' society (Bogatova 1970, p. 76; Egorov 1972, p. 34; Iudin 1992a, p. 33). These opinions are persuasive when considering the ideology of silence proposed by Ch. J. Halperin in which the Russian intellectuals at that time implicitly denied the Mongol conquest as part of their resistance to oppression (Halperin 1985, pp. 1-9, 61-74).

Therefore, although the appellation "Golden Horde" appeared for the first time in the late 16th century, its usage likely goes back further than that.

\footnotetext{
${ }^{11}$ Zelet-saltan seems to be Jalāl al-Dīn, son of Toqtamïsh (PSRL/XIX, p. 501); however, actually, the father of Tsar' Akhmat (Ahmmad), the ruler of the Great Horde is Küchük Muhammad.

${ }^{12}$ The "Golden Horde" was strongly connected with Ahmad, the ruler of the Great Horde in IKTs. There are several views about the appellation, notion, and period of the foundation of the Great Horde, but according to Trepavlov, its official appellation was "takht eli" and so forth (Trepavlov 2010, pp. 3-10). In this connection, this Ahmad was called "Aḥmad Khan of the throne (takhtnïng ahmad khān)" in Qādir 'Alī Beg's historical work written in the Kasimov Khanate at the beginning of the 17th century (Qādir "Alī Beg/S, p. 146a; Qādir "Alī Beg/K, pp. 61b, 65a). This "throne (takht)" seems to mean the throne of Saray. This indicates that the idea spread widely that the Great Horde was the state that succeeded the "Golden Horde" and the "throne" of the Jöchid (Nagamine 2014, p. 14, note 24$)$.
} 


\section{The Right and Left Wings System of the Jöchid}

Conventional research has been premised on a bipolar structure of the Right and Left Wings as the political system of the Jöchid. Moreover, many researchers connect the Right and Left Wings to the White Horde and the Blue Horde, which is explained in detail in Section 3. This Right and Left Wings system applies principles of the army formation of the Mongol Empire to domain rule, and from this perspective the Jöchid has been located in the genealogy of the empires in Central Eurasia since the Xiongnu (匈奴) and the Türk (突厥). As no special research has investigated the historical change of the Right and Left Wings system, especially of the situation after the Jöchid reintegration by Toqtamïsh, we shall examine this issue below.

\subsection{Up to the Middle of the 14th Century}

When Jöchi died in 1227 and his second son Batu became a successor of the Jöchid, the feudal estate and soldiers under the direct control of Jöchi were roughly divided between his eldest son Orda and Batu, and Orda and his four brothers were called the "princes of the left hand (dast-i chap)" (JT, p. 106a). After Batu's campaign in the west (1236-1241), while Batu and his successors held the territory west of the Urals, in the east the Ordaid took free and independent action, although the suzerainty of the Batuid was accepted. However, when Toqtagha (Toqta, r. 1291-1312) of the Batuid intervened in the power struggle of the Ordaid and Toqtagha's nephew Özbeg subordinated the Ordaid, the Ordaid lost independence (Allsen 1987, pp. 8-26).

The Jāmi ' al-Tawārìkh of Rashīd al-Dīn offers the following passage:

Toqta [= Toqtagha], emperor of Jöchi Ulus (ulīs-i jiuj $\bar{\imath})$ and Noqay, Tatar's son who was commanding soldiers on the right hand (dast-i rāst) of that ulus (JT, p. 176a).

This leads us to believe that the "right hand" (Right Wing Ulus) existed in the reign of Toqtagha. Moreover, we know that the Jöchid was divided into the "right arm" and "left arm" (Right and Left Wing Ulus) after the reign of Toqtagha in the "Anonymous Iskandar's History" and the Muntakhab al-Tawārīkh-i Mu'ìnī (hereinafter: $M T M$ ) that revised it (Extraits, p. 81). Therefore, it is presumed that the Jöchid was roughly divided into the Right Wing Ulus and the Left Wing Ulus after the reign of Toqtagha at the latest.

In $C h N$ of Ötämish Hājō, the following descriptions are found in the accounts of Berdibeg (r. 1357-1359), and of the coup d'état in which Qara Noghay of the Jöchid killed Tengiz Buga of the Qïyat tribe:

Qiyat Mamay took the right arm (ong qol) and went to the Crimea with his people. Qïyat Jir Qutlïs son Tengiz Bugha took the left arm (sol $q o l)$ and went to the banks of the Sïr (ChN, pp. 36, 50a-b).

Khị̈r Khan became khan on the throne of Saray, and Qara Noghay became khan in the left [arm] on the banks of the Sïr (ChN, pp. 41, 53a). 
According to these descriptions, the Jöchid was divided into the right arm (Right Wing Ulus) and the left arm (Left Wing Ulus) in the time of Berdibeg; thereafter, the Qiyat tribe's Mamay (or Mamaq) took the Right Wing Ulus, and the Qiyat tribe's Tengiz Buga took the Left Wing Ulus. Although the term "right arm" is not seen in the latter description, these show that the Jöchid was roughly divided into the Left Wing Ulus centring on the banks of the Sirr-Darya River and the Right Wing Ulus centring on Saray.

\subsection{After the Reintegration of the Jöchid by Toqtamïsh}

In the second half of the 14th century, Oros (r. 1368/69-1378) of the Toqa-Temürid distinguishes himself in the Left Wing Ulus. Although Oros went on an expedition to the Right Wing Ulus from the Left Wing Ulus and the Jöchid was unified for a short time, he died in the battle with Toqtamïsh of the Toqa-Temürid that freshly distinguished himself in the Left Wing Ulus. According to Zubdat al-Tawārìkh of Hāfizẹ(-i) Abrū, Temür Malik (probably Oros's son) inherited "[his father's] thousand people legion of the core (hazāra-yi așl)" in the "left arm ulus (ulūs-i qūl-i sūll)" (ZT/1, p. 535). This description clearly shows that the Left Wing Ulus existed at that time.

In 1378/79, with Timur's (founder of the Timurid Empire) support Toqtamïsh (r. 1378/79-1395) beat Temür Malik who had actually succeeded to Oros, assumed the post of khan, went on an expedition to the right wing soon thereafter, defeated Mamay and realised the reintegration of the Jöchid. The author $\left(\mathrm{Mu}^{\text {'inn }}\right.$ al-Dīn Natanzī?) of MTM reports "He [= Toqtamïsh] abolished the custom of the right arm and left arm (rasm-i qã 'ida-yi ùng qūl wa sūl qūl)" (Extraits, p. 87). This seems to confirm the fact that Toqtamïsh reintegrated the Jöchid.

Now, what happened to the political system of the Jöchid after the reintegration by Toqtamïsh? In Zafar-nāma of Sharaf al-Dīn 'Alī Yazdī, Timur's advance against the Qïpchaq Steppe west of the Volga River under the rule of Toqtamïsh in 1395 is described as a "chapter about His invincible Majesty Șāhib Qirān [= Timur] having launched an attack on the right hand of Jöchi Ulus (dast-i rāst-i ulüs-i jüjū) and Rus' territory" (ZNY, p. 277a). The description is as follows:

He [= Timur] left in the direction of the Özi River [= the Dnieper River] in that endless steppe toward the right hand ulus of Jöchi Khan (ulüs-i dast-i rāst-i jūjī khān). [omitted] Amīrzāda Mīrānshāh, Jahānshāh Bahādur, other amirs of ten thousand legions and one thousand legions returned with soldiers, and trespassed upon the direction of the right hand (barānghār) of Jöchi Ulus again. They reached Beg Khwāja and other amirs, who were punished by slaughter, capture and pillage with all the people of the right arm ulus $(u l \bar{u} s-i \bar{u} n q \bar{u} l)$. Saray, Oros and Orosjuq were also pillaged, and the entire people and territory of the ulus were placed under their rule (ZNY, pp. 277b-278a). 
In Zafar-nāma of Nizāam al-Dīn Shāmī and the Zubdat al-Tawārīkh almost exactly the same description can be found (ZNSh, p. 161; ZT/2, pp. 802-803). In the above quotation, the expression of "the right hand ulus of Jöchi Khan (ulüs-i dast-i rāst-i jujji khān)" attracts attention. It shows the Right Wing Ulus of the Jöchid, and reports that the historians of the Timurid Empire recognised the existence of the Right Wing Ulus also during the reign of Toqtamïsh. ${ }^{13}$

In addition, in a chapter slightly later than the above quotation, Yazdī described that after Timur had ruined Toqtamïsh "all the countries of the Khazar Steppe, the right hand and the left hand of the Jöchi Ulus (dast-i rāst wa dast-i chap-i ulīs-i jūjjü), and the cities in the northern direction came under his conquest and rule" (ZNY, p. 282a). There is no room for doubt regarding Yazdī's recognition of not only the Right Wing Ulus but the Left Wing Ulus too, i.e., he recognised the bipolar structure of the Right and Left Wings of the Jöchid.

Furthermore, according to $C h N$, Toqtamïsh left the "right arm (ong qol)" to 'Arab Oghlan ("Arab Shāh) of the Shïbanid after the reintegration of the Jöchid by Toqtamïsh (ChN, pp. 53-54, 59a). From this description we learn that Ötämish Hājī also recognised the existence of the Right Wing Ulus after the reintegration by Toqtamïsh.

Finally, it is necessary to describe the period of Toqtamïsh and later. Instead of Toqtamïsh, Temür Qutluq (Temür Qutlugh, r. 1397/98?-1399/1400) became a sovereign of the Jöchid. He issued a yarlïgh in the Turkic language with Uighur characters in 1398, in which he addresses and turns, among others, "to the oghlans of the right arm (ong qol) and the left arm (sol qol)" (Özyetgin 1996, pp. 106, 253). Although Temür Qutluq was from the Left Wing of the Jöchid, he took the imperial throne of Saray in 1398 supported by Edigü who was the Manghït tribe's influential chief. Therefore, this expression suggests the possibility that the Jöchid of those days consisted of the "right arm" (Right Wing Ulus) and the "left arm" (Left Wing Ulus).

To date, we have not found any source showing that the Jöchid in the 15 th century had the Right and Left Wings system. The large-scale alliance and rupture and reorganisation of nomad groups started within the Jöchid in the 15th century; therefore, it is considered that the recognition of the Right and Left Wings system eventually became meaningless. However, the Right and Left Wings system may have sporadically survived in some of the Later Jöchid states, and this should be examined.

As mentioned above, judging from the sources of the Timurid Empire other than $M T M$ or the inner sources of the Jöchid, at the time of the reintegration by Toqtamïsh or later, the Jöchid had the bipolar structure of the Right and Left Wings, even though it differed from the former, which was made by political division. Furthermore, regarding the recognition of others in the Timurid Empire, the main imperial historians clearly recognised the bipolar structure of the Right and Left Wings of the Jöchid.

${ }^{13}$ Moreover, it is interesting that Yazdī expressed the term "Right Wing" using three languages, i.e. Persian dast-i rāst, Mongolian barānghār/bara'un yar (bara'un qar) and Turkic ūn qūl/ong qol. 


\section{The Problem of the "White Horde" and the "Blue Horde"}

In the historical sources the Right and Left Wings were often denoted also by names of colour: the "White Horde (aq orda)", the "Blue Horde (kök orda)". "White Horde" and "Blue Horde" seem to refer to the colour of the ruler's pavilion, and at the same time they designated the state itself, as well as the "Golden Horde" mentioned in Section $1 .^{14}$ The early studies, based on MTM, held the view that the Blue Horde was Batu Ulus (the Right Wing) and the White Horde was Orda Ulus (the Left Wing) ${ }^{15}$. In contrast, M. G. Safargaliev and G. A. Fedorov-Davydov, using The Russian Chronicles, Khusraw and Shìrin, Mu'izz al-Ansāb and so forth, presented the view that the colours claimed by the early view were actually the opposite (Safargaliev 1960, pp. 1415; Fedorov-Davydov 1968, pp. 224-230). These researchers defined the direction for subsequent research dealing with this problem, among which Iudin's research based on ChN seems to be the most important (Iudin 1992a, pp. 24-30). The "white", in addition, was connected with the suzerain of the Jöchid; thus, it is considered that the White Horde often meant the entire Jöchid. It therefore can be said that at present many researchers of the Jöchid history accept the view that the White Horde was Batu Ulus and the Blue Horde was Orda Ulus ${ }^{16}$. In contrast, the discussion about this problem has recently been reignited mainly in the area of the former Soviet Union, and some new researchers have become involved.

Actually, at the core of this problem lies the disparate character of the outer and inner sources concerning Jöchid history. Consequently, the problem of the White Horde and the Blue Horde involves not only the problem of appellations or colours, but also deeply involves the problem of the sources that are inherent in the study of Jöchid history. Previous studies have neglected this aspect of the sources and have not payed adequate attention to it.

\footnotetext{
${ }^{14}$ The history of research dealing with the problem of the "White Horde" and the "Blue Horde" is summarised in Pishchulina (1997) and Uskenbai (2006).

${ }^{15}$ Although it was already pointed out that the descriptions of MTM regarding the genealogies and reigns of the "White Horde (i.e. the Left Wing)" rulers are incorrect, the influence of this source is so great that it is one of the reasons for the confusion in the study of Jöchid history.

${ }^{16}$ Cf. Vásáry 2009a, p. 81, note 46. Later, further research, premised on this view, has followed. For example, some of them treated the relationship between the colours and the directions ('white' means 'west' and 'blue' means 'east'). Some other studies discussed the problem of "Grey Horde (boz orda)" or "Hundred Horde (yüz orda)" connected with the Shïbanid, and dealt with the idea of "White Tsar" "and its counterargument in the study of Russian history, etc. However, it is mostly the sources written in the ruling area of the Shibanid in the later period that connected $b o z$ orda or yüz orda with the Shïbanid (for example, the description of $C h N$ above); therefore, it is not excluded that this is a false claim put forward later to increase the authority of the Shïbanid. Consequently, great care is required when interpreting boz orda or yüz orda as terms going back to the early Jöchid period (as for boz orda, see also Mustakimov 2015). In addition, the terms "White Khan (aq khān)" and "White Horde (aq orda)" were used for Boris Godunov in Qādir "Alī Beg's work (Qādir "Alī Beg/S, pp. 1a, 5a), so it is also evident that the rulers of Moscow were connected with "white" in the Kasimov Khanate at the beginning of the 17th century (Nagamine 2014, p. 23). For the designation of the Russian tsar as "white tsar"”, see Trepavlov (2007b).
} 
In this section, first we examine the recent research results, then we reconsider the problem, with special focus on the inner sources of the Jöchid.

\subsection{Recent Research}

In recent years some new research has been pursued mainly in the territory of the former Soviet Union, especially in Kazakhstan, that have tried to reinterpret the view according to which the White Horde was Batu Ulus and the Blue Horde was Orda Ulus. These studies have in common that they pay special attention to the significance of Shiban Ulus before the 14th century, which aspect was previously considered unimportant. There are views that the Blue Horde (Orda Ulus) absorbed the White Horde (Shiban Ulus), and finally became the White Horde (Pishchulina 1997, pp. 113-114), and that the White Horde was Orda Ulus and the Blue Horde was Batu Ulus, premised on the notion that colours were used only in the eastern part of the Jöchid (Mingulov 1981, pp. 79-95; Uskenbai 2006, pp. 373-378).

However, these views contain much speculation, and they are not corroborated by sufficient evidence deriving from the sources as a whole. Here we indicate two points. First, it was adduced as a rationale of the view that the notion of colours was used only in the eastern part of the Jöchid and the term "White Horde" meaning Batu Ulus is not found in The Russian Chronicles; however, actually, there is strong possibility that the Russian "White Horde" at that time meant Batu Ulus or the entire Jöchid, as mentioned below. Secondly, as a proof of the view that the Blue Horde was the Shiban Ulus, it was pointed out that the "Blue Horde (Siniaia Orda)" and the "Trans-Yayïq [= Ural River] Horde (Zaiaitskaia Orda)" correspond to Shïban Ulus; however, the "Trans-Yayïq Horde", as seen from Rus', naturally includes Orda Ulus. It thus means that the "Blue Horde" is also implied in Orda Ulus.

The most serious objection against these views is that they assume $a$ priori the identity of the White Horde with Orda Ulus (the Left Wing), with reference to the descriptions about the colours in $M T M^{17}$. In sum, the recent research that focused on the Shiban Ulus before the 14th century cannot be accepted at the moment because of lack of sufficient evidence.

\subsection{Rethinking the "White Horde" and the "Blue Horde"}

The most serious drawback of the previous studies is that they have not made a clear distinction between the outer and inner sources of the Jöchid. The outer sources sometimes include confusions, and MTM is the prime example. As was demonstrated, the descriptions of MTM include much confusion about the Jöchid, so it is not advisable

${ }^{17}$ Concerning this subject, some researchers, based on MTM, have revived the view that Oros belonged to the Ordaid; however, some serious objections have been put forward (Kostiukov 2007, pp. 195-201; Nagamine 2009, p. 23, note 15). 
to lend much weight to these descriptions about the colours. Despite the fact that various views, including some recent research, have been presented to explain the various contradictory statements in $M T M$, it is highly probable that they were originally mistakes $^{18}$.

Now that light has been shed on the questionable points of MTM as an outer source, it is to the inner sources that we must pay special attention. In Khusraw and Shìrin (completed in the middle of the 14th century), which is a contemporary source as well as an inner source (Nadzhip 1966, pp. 81-82), Tīnībeg, son of Özbeg of the Batuid line, was connected with the "White Horde". Moreover, we must regard that $C h N$ (middle of the 16th century), Bahr al-Asrār (early 17th century) and Shajara-yi Türk (late 17th century), although they belong to the sources of later periods, they unanimously state that the White Horde was Batu Ulus (the Right Wing) and the Blue Ulus was Orda Ulus (the Left Wing) ${ }^{19}$. The description of ChN quoted in Section 1 of this paper testifies that the historical memory connecting the Batuid with the "White Horde" and the Ordaid with the "Blue Horde" was preserved inside the Jöchid as late as in the middle of the 16th century.

We must pay attention also to the descriptions of the "White Horde" in The Russian Chronicles. Although the appellations "Blue Horde" and "Trans-Yayïq Horde" are often found in The Russian Chronicles after the late 14th century, the appellation connected with "white" appeared for the first time in the later period as "the White Horde (belaia vezha) of Tsar' Akhmat" (1481) in Ustiuzhskie i Vologodskie Letopisi (PSRL/XXXVII, p. 95; Vernadsky 1953, p. 139; Iudin 1992a, p. 22, note 7). It is very conspicuous that the "White Horde" was used for Ahmad of the Great Horde connected with the "Golden Horde" (see note 12 above). The pavilion of Șayïn Khan [= Batu] was described as "the white pavilion with a gold threshold" (see in ChN above) and

${ }^{18}$ Here we may refer to the genealogical information of MTM. As mentioned in note 3 , it is highly probable that the rulers of the "White Horde (i.e. the Left Wing)" that appeared in MTM actually belonged to the Toqa-Temürid, not to the Ordaid as previously assumed. In addition, almost all the persons who became the khans of the "Blue Horde (i.e. the Right Wing)" from the khan's family of the "White Horde" in this source, belonged to the Shïbanid. As Khïdr was mentioned among them, it corresponds to the description of $C h N$ that Khïdr of Shïbanid ascended to the throne of Saray (ChN, pp. 36, 50b; Iudin 1992b, pp. 66-67). The above leads to some confusion about the genealogical information of MTM: its author, although used the fragmentary information about the khans of Toqa-Temürid and Shïbanid descent who rose after the end of the Batuid and the Ordaid, was ignorant of their precise origins and erroneously linked all of them to one straight family tree.

${ }^{19}$ The headquarters of Jöchi was called the "Blue Horde" in the Shajara-yi Türk (Histoire, p. 172); this seems to reflect that Jöchi's eldest son Orda succeeded his father's headquarters and founded the Orda Ulus (the Left Wing) that came to be called the "Blue Horde". However, the Firdaws al-Iqbāl connected the "Blue Horde" with the Batuid erroneously (FI, pp. 95, 97). In the Shajara-yi Türk and Bahr al-Asrär, the "White Horde" was connected with the Shïbanid that seems to have belonged to the Batu Ulus (the Right Wing); besides, Bahr al-Asrār recounts that the "White Horde" was also called yüz orda (Histoire, p. 173; BA, p. 115a; Fedorov-Davydov 1968, pp. 229-230). However, these descriptions about the Shïbanid can be the reflection of false claims made later (see note 16 above). In addition, the Left Ulus (Orda Ulus) was called the "Blue Horde" in the $M u$ ' $i z z$ al-Ansāb that seems to have been compiled in the Timurid and the Mughal Empires, albeit it is an outer source (MA, p. 18b). 
all these indicate that the "Golden Horde" and the "White Horde" were often used synonymously $^{20}$. In contrast, although it has hitherto not attracted much attention, there is a yarligh in Turkic with Uighur characters, issued by Toqtamïsh in 1393 and addressed to Jagiello (Iagaila), the ruler of Lithuania and Poland, the Russian translation of which seems to be contemporaneous with it. The translation of the original text of the yarligh reads as follows:

It [= intercommunication of merchants from both countries] will be good/beneficial for the peace of the ulugh ulus, so I granted this yarligh with the gold seal (Özyetgin 1996, pp. 105-106, 252).

In the Russian translation the term "ulugh ulus" was replaced with "White Horde (Belaia Orda)" (Berezin 1850, pp. 22, 66; Mustakimov 2015, pp. 138-139). This indicates that the first appearance of the Russian "White Horde" probably goes back to earlier times than the Ustiuzhskie $i$ Vologodskie Letopisi. This yarligh was issued after the reintegration of the Jöchid by Toqtamïsh; therefore, the "White Horde" that appeared here may mean the entire Jöchid realm under the rule of Toqtamïsh $^{21}$. The fact that the term "ulugh ulus" was translated into Russian as "White Horde" is all the more significant since this translation seems to reflect the historical knowledge of the time. As we have already pointed out in Section 1, the appellation "Golden Horde" may have been used as a synonym for the "ulugh ulus/orda (Great Ulus/Horde)". Taking this and other statements of this chapter into account, in all likelihood the terms "Golden Horde", "White Horde" and "ulugh ulus/orda" were interchangeable and used synonymously with reference to the entire Jöchid realm. ${ }^{22}$

Although it is difficult to judge whether the "White Horde" and the "Blue Horde" were appellations used consistently from the foundation of the Jöchid, from the above discussion one can conclude that, at least by the late 14th century, the "White Horde" referred to Batu Ulus (the Right Wing) or the entire Jöchid realm, while the "Blue Horde" referred to Orda Ulus (the Left Wing).

\section{Conclusion}

In Section 1 we summarised the discussions about the appellations of the Jöchid, and re-examined the essence of the term "Golden Horde", utilising the description of the Hei-da shi-lüe, and pointed out that the appellation of the Jöchid as "Golden Horde" may go back further than the late 16th century. In Section 2 the "Right and Left Wings" system of the Jöchid was investigated. It was demonstrated that the Jöchid

\footnotetext{
${ }^{20}$ Each term, i.e. 'west', 'gold' and 'white' has a parallel in the so-called Five Elements Theory of China.

${ }^{21} \mathrm{~K}$. Uskenbai, who has the view that the White Horde was Orda Ulus and the Blue Horde was Shïban Ulus, interprets that this "White Horde" was due to Toqtamïsh's belonging to the White Horde (Orda Ulus) (Uskenbai 2006, p. 376); however, we cannot concur with this statement.

${ }_{22}$ As for the synonymity of the terms "Golden Horde", "White Horde" and "ulugh ulus/orda", see also Mustakimov (2015, pp. 138-140).
} 
had been divided into Right and Left Wings after the reign of Toqtagha at the latest and this bipolar structure continued to exist even after the reunification of both wings by Toqtamïsh, something that historians in the Timurid Empire also clearly recognised. In Section 3 the appellations "White Horde" and "Blue Horde" were scrutinised, with special regard to the first appearance of the "White Horde" in the Russian historical sources, and its implications. On the basis of this study the conclusion was drawn that, at least by the late 14th century, the term "White Horde" referred to the Right Wing or the entire Jöchid realm, while the "Blue Horde" referred to the Left Wing.

However, one must raise the following questions: (1) Why did the appellations "White Horde" and "Blue Horde" appear in the sources from the late 14th century onward, and (2) Why did Rus' society start to use the term "Golden Horde" after the 16 th century? Actually, we do not have obvious answers to these questions, yet we dare to put forward two assumptions. First, the appearance of the appellations "White Horde" and "Blue Horde" may be strongly connected to the emergence of the bipolar structure in the Jöchid realm. A clue to the latter question may be that the domination of the Jöchid over Rus' society was weakening from the late 14th century until the 16 th century. This means that it became unnecessary to avoid the use of the glorious modifying word "gold" as a form of resistance to the oppression of the Jöchid. Furthermore, both questions can be connected to the activations of the Left Wing or Shïban Ulus, and the foundations of the Later Jöchid states thereafter. That is to say, basing on the Russian sources, one may think that Rus' labelled the Jöchid "Orda" as one state before, but after the political shifts of the Jöchid, later it became necessary to distinguish the state centring on Saray (the "Golden Horde", the "White Horde" and the "Great Horde") from the "Blue Horde", the "Trans-Yayïq Horde" and the other Later Jöchid states.

\section{Abbreviations and References}

Allsen, Th. T. (1987): The Princes of the Left Hand: An Introduction to the History of the Ulus of Orda in the Thirteenth and Early Fourteenth Centuries. AEMA Vol. 5, pp. 5-40.

BA: Mạ̣mūd b. Walī: Baḥr al-Asrār fī Manāqib al-Akhyār. MS. IB AN UzSSR, No. 1375.

Berezin, I. N. (1850): Khanskie iarlyki, I. Iarlyk Tokhtamysh khana k Iagailu. Kazan.

Bogatova, G. A. (1970): Zolotaia Orda. Ruskaia rech' (Moscow) No. 1, pp. 70-77.

Carpini/D: Mission to Asia: Narratives and Letters of the Franciscan Missionaries in Mongolia and China in the Thirteenth and Fourteenth Centuries. Translated by a nun of Stanbrook Abbey, edited by Dawson, Ch. New York, Harper \& Row Publishers, 1980.

Carpini/M: Giovanni di Pian Carpine: Storia dei Mongoli. Edited by Menestò, E. et al. Spoleto, Centro italiano di Studi sull'Alto Medioevo, 1989.

$C h N$ : Ötämiš Hāàjī: Čingīz-nāma. Edited and translated by Kawaguchi, T.-Nagamine, H. Tokyo, Research Institute for Language and Cultures of Asia and Africa, 2008 (Studia Culturae Islamicae, 94).

ChN/Iudin: Utemish-khadzhi: Chingiz-name. Edited and translated by Iudin, V. P. Alma-Ata, Gylym, 1992.

Collins, L. (1991): On the Alleged "Destruction" of the Great Horde in 1502. In: Bryer, A. - Ursinus, M. (eds): Byzantinische Forschungen: Internationale Zeitschrift für Byzantinistik, XVI, 
Manzikert to Lepanto: The Byzantine World and the Turks 1071-1571. Amsterdam, pp. $361-399$.

Egorov, V. L. (1972): Gosudarstvennoe i administrativnoe ustroistvo Zolotoi Ordy. Voprosy istorii (Moscow) No. 2, pp. 32-42.

Extraits: Extraits du Muntakhab al-Tavarikh-i Mu'ini (Anonyme d'Iskandar). Edited by Aubin, J. Tehran, Librairie Khayyam, 1957.

Fedorov-Davydov, G. A. (1968): «Anonim Iskendera» i terminy «Ak-Orda» i «Kok-Orda». In: Vinogradova, A. V. et al. (eds): Istoriia, arkheologiia i ètnografiia Srednei Azii: K shestidesiatiletiiu so dnia rozhdeniia S.P. Tolstova. Moscow, Izd-vo «Nauka», pp. 224-230.

FI: Shīr Muhammad Mīrāb Mūnis and Muḥammad Riżā Mīrāb Āgahī: Firdaws al-Iqbāl: History of Khorezm. Edited by Bregel, Y. Leiden-New York-København-Köln, Brill, 1988.

Gaev, A. G. (2002): Genealogiia i khronologiia Dzhuchidov: K vyiasneniiu rodosloviia numizmaticheski zafiksirovannykh pravitelei Ulusa Dzhuchi. In: Petrov, P. N. (ed.): Drevnosti Povolzh'ia i drugikh regionov. Vyp. IV, Numizmaticheskii sbornik, Tom 3. Nizhny Novgorod, pp. 9-55.

Halperin, Ch. J. (1985): Russia and the Golden Horde: The Mongol Impact on Medieval Russian History. Bloomington, Indiana University Press.

Hamamoto, M. (2011): Kyōsē no isulāmu: Rosia no sēkyōto to musurimu [Symbiotic Islām: Russian Orthodox Christians and Muslim]. Tokyo, Yamakawa Shuppansha (in Japanese).

Hei-da shi-lüe: Peng Da-ya 彭大雅-Xu Ting 徐霆: Hei-da shi-lüe 黑鞋事略. In: Wang Guo-wei 王國維 (ed.): Meng-da bei-lu Hei-da shi-lüe jian-zheng 蒙韃備録・黑鞋事略箋證. Beiping 北平, Wen-dian-ge shu-zhuang 文殿閣書莊, 1936 (Guo-xue wen-ku 國學文庫, 25).

Histoire: Histoire des Mogols et des Tatares par Aboul-Ghâzi Bèhâdour Khan, Tome I, texte. Edited by Le Baron Desmaisons. St. Pétersbourg, 1871. (Reprint: Amsterdam, Philo Press, 1970.)

Ibn Batțūtạa/DS: Voyages d'Ibn Batoutah, Tome II. Edited and translated by Defrémery, C. - Sanguinetti, B. R. Paris, L'Imprimirie Nationale, 1877.

Ibn Bațtūṭa/G: The Travel of Ibn Battututa: A.D. 1325-1354, Vol. II. Translated by Gibb, H. A. R. Cambridge, The Hakluyt Society, 1959.

Iudin, V. P. (1992a): Ordy: Belaia, Siniaia, Seraia, Zolotaia. In: ChN/Iudin, pp. 14-56.

Iudin, V. P. (1992b): Perekhod vlasti k plemennym biiam i neizvestnoi dinastii Tokatimuridov v kazakhskikh stepiakh v XIV v. (K probleme vostochnykh pis'mennykh istochnikov, stepnoi ustnoi istoriografii i predystorii Kazakhskogo khanstva). In: ChN/Iudin, pp. 57-75.

Izmailov, I. (2009): Ulus Dzhuchi i Zolotaia Orda: ofitsial'noe nazvanie strany i istoricheskaia traditsiia. In: Usmanov, M. - Khakimov, R. (eds): Istoriia Tatar: S drevneishikh vremen, v semi tomakh, Tom III, Urus Dzhuchi (Zolotaia Orda): XIII-seredina XV v. Kazan, In-t istorii im. Sh. Mardzhani AN RT, pp. 16-19.

JT: Rashīd al-Dīn Faḍl Allāh Hamadānī: Jāmi` al-Tawārīkh. MS. Topkapı Sarayı Müzesi Kütüphanesi, Revân köşkü, 1518.

Kawaguchi, T. (1997): Kipuchaku sōgen to roshia [Kipchak Steppe and Russia]. In: Kabayama, K. et al. (eds): Iwanami kōza sekai rekishi, 11, chūō yūrashia no tōgō: 9-16 seiki [Iwanami lectures on world history, 11, Unification of Central Eurasia: 9th-16th centuries]. Tokyo, Iwanami Shoten, pp. 275-302 (in Japanese).

Kawaguchi, T. - Nagamine, H. (2010): Nekotorye novye dannye o «Chingiz-name» Utemisha-khadzhi: v sisteme istoriografii v Dasht-i Kipchake. Zolotoordynskaia tsivilizatsiia (Kazan) Vyp. 3, pp. 44-52.

Kawaguchi, T. - Nagamine, H. (2013): Jochi urusu shi saikō [Rethinking the history of Ulūs-i Jū-

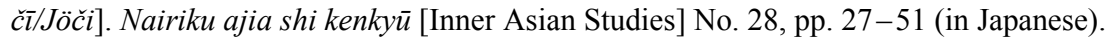


Kostiukov, V. P. (2007): Ulus Dzhuchi i sindrom feodalizma. Voprosy istorii i arkheologii zapadnogo Kazakhstana No. 1, pp. 169-207.

MA: (Anonym) Mu'izz al-Ansāb fī Shajarat Salāṭ̄n Mughūl. MS. Bibliothèque Nationale, Ancien fonds, Persan 67.

Mingulov, N. N. (1981): K nekotorym voprosam izucheniia istorii Ak-Ordy. In: Margulan, A. Kh. (ed.): Kazakhstan v épokhu feodalizma (Problemy etnopoliticheskoi istorii). Alma-Ata, Izdvo «Nauka» Kaz. SSR, pp. 79-95.

Mirgaleev, I. M. (2011): «Chingiz-name» Utemisha-khadzhi: Perspektivy izucheniia. Zolotoordynskaia tsivilizatsiia (Kazan) Vyp. 4, pp. 14-19.

Mitroshkina, A. G. (1969): Termin «Zolotaia Orda». Trudy Irkutskogo universiteta Tom 65, Vyp. 4, pp. 25-32.

MTM: Muntakhab al-Tawārīkh-i Mu'īnī, see Extraits.

Mustakimov, I. A. (2009a): Ob odnom spiske «Daftar-i Chingiz-name». Srednevekovye tiurkotatarskie gosudarstva (Kazan) Vyp. 1, pp. 122-131.

Mustakimov, I. A. (2009b): Eshche raz k voprosu o predkakh «Mamaia-tsaria». In: Kliashtornyi, S. G. - Sultanov, T. I. - Trepavlov, V. V. (eds): Tiurkologicheskii sbornik 2007-2008: Istoriia $i$ kul'tura tiurkskikh narodov Rossii i sopredel'nykh stran. Moscow, Izd. firma «Vost. litra» RAN, pp. 273-283.

Mustakimov, I. A. (2012): Gosudarstvennoe ustroistvo, territorial'nyi sostav i ėtnosotsial'naia struktura Dzhuchieva Ulusa XIII-XVI vv. Avtoreferat diss. k.i.n. Kazan.

Mustakimov, I. A. (2015): Eshche raz k voprosu o tsvetooboznacheniiakh ord v Uluse Dzhuchi (termin Boz-Orda v istochnikakh XVI-XIX vv.). In: Zolotoordynskoe obozrenie (Kazan), No. 2, pp. 129-149.

Nadzhip, E. N. (1966): «Khosrau i Shirin» Kutba i ego iazyk. In: Kliashtornyi, S. G. - Petrosian, Iu. A. - Tsel'niker, S. S. (eds): Tiurkologicheskii sbornik: K shestidesiatiletiiu A. N. Kononova. Moscow, Izd-vo «Nauka», pp. 80-91.

Nagamine, H. (2009): "Kazaku han koku" keisei shi no saikō: jochi urusu sayoku kara "kazaku han koku" he [Rethinking the Foundation of the "Qazaq Khanate": From the Left Hand of the Ulūs-i Jūchi to the "Qazaq Khanate"]. Tōyō gakuhō [Journal of the Research Department of the Toyo Bunko] Vol. 90, No. 4, pp. 1-26 (in Japanese).

Nagamine, H. (2014): Kādhiru arī begu no shisho ni tsuite: Jochi urusu kēshō sēken shiryō no shiryō teki kachi to sono rekishi ninshiki [On Qādir 'Alī Beg's Historiography: Values as Sources and Historical Perceptions of the Historiographies of Successor States to Ulūs-i Jūchī/Jöchi]. Isuramu sekai [The world of Islam] No. 81, pp. 1-31 (in Japanese).

Ostrowski, D. (1998): Muscovy and the Mongols: Cross-Cultural Influences on the Steppe Frontier, 1304-1589. Cambridge, Cambridge University Press.

Özyetgin, A. M. (1996): Altın Ordu, Kırım ve Kazan Sahasına ait Yarlık Bitiklerin Dil ve Üslûp Ince-lemesi. Ankara, Alıç Ofset Matbaacılık Sanayi Ticaret A. Ş.

Pétis de la Croix, F. (1710): Histoire du Grand Genghizcan: Premier Empereur des Anciens Mogols et Tartares. Paris, Chez la veuve Jombert.

Pishchulina, K. A. (1997): Ak-Orda v XIV veke. In: Kozybaev, M. K. et al. (eds): Istoriia Kazakhstana: $S$ drevneishikh vremen do nashikh dnei, v piati tomakh, Tom 2. Almaty, Izd-vo «Atamura», pp. 103-116.

PSRL/XIX: Polnoe sobranie russkikh letopisei, XIX. Istoriia o Kazanskom tsarstve (Kazanskii Letopisets). S.-Peterburg, 1903. (Reprint: Moscow, Iazyki russkoi kul'tury, 2000.)

PSRL/XXXVII: Polnoe sobranie russkikh letopisei, XXXVII, Ustiuzhskie i Vologodskie Letopisi XVIXVIII vv. Leningrad, Nauka, 1982. 
Qādir ‘Alī Beg/K: Qādir 'Alī Beg’s Historical Work. MS. Otdel rukopisei i redkikh knig Nauchnoi biblioteki im. N. I. Lobachevskogo Kazanskogo gosudarstvennogo universiteta, 40T.

Qādir 'Alī Beg/S: Qādir 'Alī Beg's Historical Work. MS. Vostochnyi otdel Nauchnoi biblioteki im. M. Gorskogo Sankt-Peterburgskogo gosudarstvennogo universiteta, MsO. 59.

Rubruck (1990): William of Rubruck: The Mission of Friar William of Rubruck: His Journey to the Court of the Great Khan Möngke 1253-1255. Edited by Jackson, P. - Morgan, D. London, The Hakluyt Society.

Safargaliev, M. G. (1960): Raspad Zolotoi Ordy. Saransk, Mordovskoe knizh. izd-vo.

Schamiloglu, U. (1984): The Qaraçi Beys of the Golden Horde: Notes on the Organization of the Mongol World Empire. AEMA Vol. 4, pp. 283-297.

Schamiloglu, U. (1986): Tribal Politics and Social Organization in the Golden Horde. Ph. D. Dissertation. Columbia University.

Shiraishi, N. (2006): Avraga Site: The 'Great Ordū' of Genghis Khan. In: Komaroff, L. (ed.): Beyond the Legacy of Genghis Khan. Leiden-Boston, Brill (Islamic History and Civilization: Studies and Texts, 64), pp. 83-93.

Sinica: Sinica Franciscana I: Itinera et relationes fratrum minorum saeculi XIII et XIV. Edited by Wyngaert, Anastasius von den. Quaracchi-Firenze, Collegium S. Bonaventurae, 1929.

Trepavlov, V. V. (2007a): Predki «Mamaia-tsaria». Kiiatskie beki v «Podlinnom rodoslove Glinskikh kniazei». In: Kliashtornyi, S. G. - Sultanov, T. I. - Trepavlov, V. V. (eds): Tiurkologicheskii sbornik 2006. Moscow, Izd. firma «Voct. lit-ra» RAN, pp. 319-352.

Trepavlov, V. V. (2007b): «Belyi tsar'.» Obraz monarkha i predstavleniia o poddanstve u narodov Rossii $X V-X V I I I v v$. Moscow, Vostochnaia literatura.

Trepavlov, V. V. (2010): Bol'shaia Orda - Takht eli: Ocherk istorii. Tula, «Grif i K».

Uskenbai, K. (2006): Ulusy pervykh Dzhuchidov: Problema terminov Ak-Orda i Kok-Orda. In: Kliashtornyi, S. G. - Sultanov, T. I. - Trepavlov, V. V. (eds.): Tiurkologicheskii sbornik 2005: Tiurkskie narody Rossii i Velikoi stepi. Moscow, Izd. firma «Voct. lit-ra» RAN, pp. 355382.

Vásáry, I. (2009a): The Jochid Realm: The Western Steppe and Eastern Europe. In: Cosmo, N. D. Frank, A. J.-Golden, P. B. (eds): The Cambridge History of Inner Asia: The Chinggisid Age. Cambridge, Cambridge University Press, pp. 67-85.

Vásáry, I. (2009b): The Beginnings of Coinage in the Blue Horde. AOH Vol. 62, No. 4, pp. $371-$ 385.

Vásáry, I. (2012): The Crimean Khanate and the Great Horde (1440s-1500s): A Fight for Primacy. In: Klein, D. (ed.): The Crimean Khanate between East and West (15th-18th Century). Wiesbaden, Harrassowitz Verlag (Forschungen zur osteuropäischen Geschichte, 78), pp. $13-26$.

Vernadsky, G. (1953): A History of Russia, Vol. III, The Mongols and Russia. New Haven, Yale University Press.

ZNSh: Histoire des conquêtes de Tamerlan intitulée Zafarnāma par Nizāmuddīn Šāmì avec des additions empruntées au Zubdatu-t-tawārīh-i Bāysungurū de Hāfiz-i Abrū, Tome I. Edited by Tauer, F. Praha, Oriental Institute, 1937.

ZNY: Sharaf al-Dīn 'Alī Yazdī: Zafar-nāma. Edited by Urunbaev, A. Tashkent, Uz. SSR «Fan», 1972.

ZT: Ḥāfiż(-i) Abrū: Zubdat al-Tawārīkh, Vols 1-2. Edited by Sayyid Kamāl Ḥājj Sayyid Jawādī. Tehran, Sāzmān-i chāp wa intishārāt-i wazārat-i farhang wa irshād-i Islāmī, 1380. 
